Yayın Geliş Tarihi: 09.10.2020

Yayına Kabul Tarihi: 15.01.2021

Online Yayın Tarihi: 31.03.2021

http://dx.doi.org/10.16953/deusosbil.808359
Dokuz Eylül Üniversitesi

Sosyal Bilimler Enstitüsü Dergisi

Cilt: 23, Say1: 1, Y11: 2021, Sayfa: 455-479

ISSN: 1302-3284

E-ISSN: 1308-0911

Derleme Makalesi

\title{
SÜPER AKILLI TOPLUM: TOPLUM 5.0
}

Emin Sertaç ARI*

$\ddot{O} z$

Bilgi ve iletişim teknolojisinin hızl gelişimi, topluma ve sektörlere büyük değişiklikler getirmektedir. Dijital dönüşüm yeni değerler yaratmakta ve birç̧o ülkede sanayi politikasinın temel direği haline gelmektedir. Bu bağlamda Japonya, dijital dönüşümü merkezine koyarak toplumların gelişiminin beşinci aşaması olan Süper Akıllı Toplumu dünyaya tanitmaktadır. Toplum 5.0, Japonya tarafindan ortaya konan, beşinci aşama olarak adlandırllan yeni bir insan merkezli toplum vizyonudur. Bu çalıșada Almanya'nın "Endüstri 4.0" vizyonunu içeren günümüz bilgi toplumunun doğal bir uzantısı olarak da ifade edilebilen Toplum 5.0'ın çeşitli perspektifler dahilinde toplumun yaşam kalitesini artırmayı hedefleyen amaç, enstrüman ve olası çıktılarına detaylı biçimde yer verilmektedir.

Anahtar Kelimeler: Toplum, Endüstri, Dijital dönüşüm, Sürdürülebilirlik, Akıllı

\section{SUPER SMART SOCIETY: SOCIETY 5.0}

\begin{abstract}
The rapid development of information and communication technology brings great changes to society and sectors. Digital transformation creates new values and becomes the main pillar of industrial policy in many countries. In this context, Japan launches digital transformation at its center and introduces the Super Smart Society, the fifth stage of the development of societies, to the world. Society 5.0 is a new vision of people-centered society put forward by Japan, called the fifth stage. In this study, the purpose, instrument and possible outputs of Society 5.0, which can be expressed as a natural extension of today's information society, which includes Germany's vision of "Industry 4.0", aims to increase the quality of life of the society in various perspectives.
\end{abstract}

Keywords: Society, Industry, Digital transformation, Sustainability, Smart

Bu makale için önerilen kaynak gösterimi (APA 6. Sürüm).

Arı, E. S. (2021). Süper akıllı toplum: Toplum 5.0. Dokuz Eylül Üniversitesi Sosyal Bilimler Enstitüsü Dergisi, 23 (1), 455-479.

*Dr. Öğretim Üyesi, Osmaniye Korkut Ata Üniversitesi, İktisadi ve İdari Bilimler Fakültesi, Yönetim Bilişim Sistemleri, ORCID: 0000-0003-4453-5528,_sertacari@ osmaniye.edu.tr. 
Arl, E.S.

DEÜ SBE Dergisi, Cilt: 23, Sayl: 1

\section{GİRIŞ}

Tarih boyunca insanlık daha iyi bir yaşam sürmenin yollarını aramış ve bunu sağlamak için her seferinde bir sonraki aşamaya geçişte dünyayı değiştirecek birtakım tetikleyici gelişme ortaya koymuştur. Milat sayılan söz konusu gelişmeler daha sonra ilgili tarih yazıcıları tarafından yeni bir toplum jenerasyonunun başlatıcı fenomeni olarak adlandırılmıştır.

Sonuçlanma ivmelerinin gitgide azalmış olduğu görülse de her bir jenerasyonun ortaya çıkmasına sebep olan gelişme bir bilgi ve teknoloji arayışının doğal sonucudur. Gelinen noktada günümüzde de bilgi ve iletişim teknolojisinin hızlı gelişiminin topluma ve sektörlere büyük değişiklikler getirdiği görülmektedir. Dijital dönüşüm yeni değerler yaratarak birçok ülkede sanayi politikalarının temel direği haline gelmiş durumdadır. Günümüz ekonomilerinin lokomotif sektörleri ile dünyanın en değerli firmalarının teknoloji firmaları olduğu ortadadır.

Japonya'nın İkinci Dünya Savaşı sonrasında yeniden ayağa kalkarak kısa süre içerisinde dünya devi olmasında Tam Zamanında Üretim, Kaizen, Toplam Kalite Yönetimi gibi yönetim ve üretim felsefelerinin büyük rolü olmuştur. Söz konusu yaklaşımlar tüm çalışanların katılımını, çalışanların fikirlerine önem verilmesini, sürekli iyileştirme düşüncesini ve tepe yönetimin tam desteğini gerektirmektedir (Öztuna, 2019). Yine Japonya tarafindan lansmanı yapılan Toplum 5.0 inisiyatifi kapsamında bu kez teknoloji destekli toplumsal bir dönüşüm girişimi, Birleşmiş Milletler Sürdürülebilir Kalkınma Amaçları manifestosunda sunulan 17 madde rehber edinilerek ortaya konmaktadır.

Söz konusu inisiyatif prensip olarak merkezî oluşumları dışarıda tutarak her alanda dağıtık sistemleri desteklemekte, dijital dönüşüm fenomeni ve enstrümanları sayesinde bu şekilde dönüştüreceği topluma sağlıklı ve kaliteli bir yaşam, içi dolu bir eğitim, eşit bir toplum, temizlik ve hijyene erişim, sürdürülebilir üretim ve tüketim, temiz enerji, adalet ve en önemlisi verimli iş birlikleri vadetmektedir.

Bu çalışma Japonya devleti tarafindan ortaya konarak 2017 yılında lansmanı yapılan Toplum 5.0 dönüşümünü ortaya koyarak pek çok açıdan değerlendirmektedir. Çalışmada öncelikle bu yeni kavramın ne olduğu tartışılmakta, bundan önceki dört evre ve bunların tetikleyici gelişmeleri kısaca ortaya konmakta, ardından söz konusu toplumsal dönüşümün dinamikleri olan dijital dönüşüm kavramından bahsedilmekte, akabinde dönüşüm rehber edindiği sürdürülebilir kalkınma amaçları bağlamında çeşitli başlıklar altında değerlendirilmektedir. Ayrıca söz konusu radikal dönüşümün olası sonuçları sıralanmakta, Türkiye'nin bu dönüşüm öncesinde durduğu yer ve dönüşüme entegre olmak ve sisteme ayak uydurmak için yapılması gerekenler ifade edilmektedir. 


\section{TOPLUM 5.0 NEDIR?}

Toplum 5.0, Japonya'nın 2016-2021 mali y1lları arasını kapsayan 5. Bilim ve Teknoloji Ana Planında sunularak 22 Ocak 2016 tarihinde Bakanlar Kurulu tarafindan onaylanan; esin kaynağı olarak düşünülebilecek Endüstri 4.0'a benzer biçimde lansmanı Almanya'nın Hannover şehrinde düzenlenen Bilişim Teknolojileri Fuarı CeBIT 2017'de bizzat dönemin Japonya Başbakanı Shinzo Abe tarafından yapılan ve basitçe "dünyadaki dijital dönüşümün etkisini demografik, ekonomik, etik ve sosyolojik yönden değerlendirerek insanların makine ve robotlarla ilişkisinin en verimli biçimde sağlandığ 1 toplumsal dönüşüm felsefesi (Develi, 2017)" olarak tanımlanabilen; "Dijital Toplum", "Yaratıcı Toplum" ya da en yaygın tabiriyle "Süper Akıllı Toplum" olarak ifade edilen yeni toplum modelinin adıdır.

Son yıllarda yaşanan baş döndürücü teknolojik değişim ve bunun sonucunda ortaya çıkan yapay zekâ, nesnelerin interneti (IoT), robotik, blok zincir, nanoteknoloji, dijital dönüşüm gibi kavramların günlük hayata entegre olması ve ilerleyen süreçte çok daha fazlasına şahit olunacağı beklentisiyle özellikle bu teknolojileri üreten ve dünyaya sunan ülkeler birtakım makro stratejiler belirlemiş ve uzun vadeli planlarını bu bağlamda güncellemişlerdir. İlk kez 2011 yılında Almanya tarafindan ortaya konan "Industrie 4.0" ${ }^{1}$ ve 2015 yılında lansmanı yapilan "Made in China 2025" ${ }^{2}$ bu konuda değişimi destekleyen öncü stratejilerdir. Söz konusu stratejiler ve planlar birtakım değişimlerin sonucunda ortaya çıkan, kaçınılmaz olan ancak iyi yönetildiği takdirde ilerleyen teknolojiye uyumlu biçimde yaşanan ekonomik ve jeopolitik değişimdir. Dünya ekonomisinin ağırlık merkezi batıdan Asya'ya kaymakta, bazı ülkeler çok düşük doğum oranlarından kaynaklı yaşlı nüfus tehlikesiyle karşı karşıya kalmakta, öte yandan global nüfus hızla artmaktadır. Üçüncü değişim ise zihinsel değişim olarak genelleştirilebilecek olan; dünyada su kirliliği, temiz enerji, doğal hayat, iklim değişikliği gibi ekolojiye dayalı konular ile toplumsal eşitsizliğin artması, yoksulluk, açlık, cinsiyet eşitliği gibi kavramların önem ve hassasiyet kazanması ve pek çok alanda girişimlerin odağına konmasıdır. Bu bağlamda Birleşmiş Milletler 2015 yılında "Sürdürülebilir Kalkınma Amaçları" " ${ }^{3}$ başlığı altında 17 maddelik bir manifesto yayınlamıştır (Birleşmiş

\footnotetext{
${ }^{1}$ Endüstri 4.0; ilk kez 2011 yılında Almanya tarafından duyurulan, bilgi ve iletişim teknolojisi yardımıyla endüstriye yönelik makine ve süreçlerin akıllı ağını ifade eden kavramdır. Ayrıntılı bilgi için Endüstri 4.0 Platformu resmî web sayfası: https://www.plattform-i40.de/PI40/Navigation/EN/Home/home.html

${ }^{2}$ Made in China 2025, Çin Halk Cumhuriyeti'nin Mayıs 2015'te yayınladığı stratejik plandır. Bu planla birlikte Çin, "dünyanın fabrikası" (düşük işçilik maliyetleri ile ucuz, düşük kaliteli ürünler üreten) imajından kurtulacak ve katma değeri yüksek ürünler üreten ülke konumuna yükselecektir. Ayrıntılı bilgi için Made in China 2025 resmî web sayfası: http://english.www.gov.cn/2016special/madeinchina2025/

${ }^{3}$ Sürdürülebilir Kalkınma Amaçları, herkes için daha iyi ve daha sürdürülebilir bir gelecek elde etme planıdır. Yoksulluk, eşitsizlik, iklim değişikliği, çevresel bozulma, barış ve adalet 
Milletler, 2015). Bu amaçlar Yoksulluğa Son, Açlığa Son, Sağlık ve Kaliteli Yaşam, Nitelikli Eğitim, Toplumsal Cinsiyet Eşitliği, Temiz Su ve Sanitasyon, Erişilebilir ve Temiz Enerji, İnsana Yakışır İş ve Ekonomik Büyüme, Sanayi Yenilikçilik ve Altyapı, Eşitsizliklerin Azaltılması, Sürdürülebilir Şehirler / Topluluklar, Sorumlu Üretim / Tüketim, İklim Eylemi, Sudaki Yaşam, Karasal Yaşam, Barış Adalet / Güçlü Kurumlar ve Amaçlar İçin Ortaklıklar olarak sıralanabilir.

\section{TOPLUMLARIN EVRIMI}

İnsanlık tarihi boyunca insanoğlu kalıpları önceden belirlenmiş bir sistem içerisinde yaşama şansına sahip olamamış, bütün toplumsal yaşam modellerini o dönemin ihtiyaç ve koşulları biçimlendirmiştir (Canlığlu, 2008). Bilim, özellikle bilginin kullanımına dayalı tetikleyici gelişmelerin biçim verdiği farklı özellikler gösteren toplumsal yapıları tarihsel tutarlılık içerisinde sonradan adlandırmış ve özellikleri bağlamında ayrıştırmıştır. Toplum 5.0'ı anlamak ya da en azından beşinci nesil topluma gelene kadar insanlığın kat etmiş olduğu aşamaları görmek adına daha önce tanımlanmış olan toplum modellerine ve bu toplumların tarihsel özelliklerine kısaca değinmekte fayda vardır. Japonya İş Federasyonu Keidanren söz konusu toplumları Avc1-Toplayıc1 Toplumdan Süper Akıllı Topluma uzanan skalada versiyonlar biçiminde kategorize etmiştir (Keidanren, 2018). Toplumlar ve özellikleri kısaca aşağıdaki gibi açıklanabilir:

- Toplum 1.0 (Avcı-Toplayıcı Toplum): İnsanlığın ortaya çıkışıyla birlikte insanoğlu bilgiyi doğaya hükmetmek için, hayatta kalmak amacıyla kullanmaya başlamıştır. O dönemde en temel güdüler olan beslenme ve diş tehditlerden (doğal felaket, vahşi hayvan, vs.) korunma amaciyla pek çok yöntem geliştirmiş ve türünü sürdürülebilir kılmıştır. İlk insanın doğayla mücadelesinde onu doğaya üstün kılacak donanımının olmamas1 insanoğlunun bilgiyi kullanarak sonraki çağlarda gelişmiş medeniyetler geliştirmesini sağlamıştır (Sezer, 2018).

- Toplum 2.0 (Tarım Toplumu): Tarım toplumu ilkel yaşam şartlarındaki insanın avcılık ve toplayıcılıktan sonra bitki türlerini evcilleştirmeyi; güneş, su ve topraktan faydalanmayı ögrenmesinden sonra zamanla tarım faaliyetlerine başlaması ve yerleşik hayata geçişiyle şekillenen toplum yapısıdır (Canlıoğlu, 2008). Tarihsel anlamda insanoğlunun yerleşik hayata geçmeye başladığı M.Ö. 13.000'li yıllardan M.S. 18. yüzyıl ortalarındaki 'Sanayi Devrimi'ne kadar devam etmiştir. Bu süreçte dünya nüfusu artmaya, bugün bildiğimiz anlamda köy ve şehirler kurulmaya; sosyal, kültürel ve ekonomik yaşam ile ilişkiler şekillenmeye başlamıştır. Bilgiyi kullanarak

de dahil olmak üzere karşılaşılan küresel sorunları ele almaktadır. Ayrıntılı bilgi için Birleşmiş Milletler Sürdürülebilir Kalkınma Amaçları resmî web sayfası: https://www.un.org/sustainabledevelopment/sustainable-development-goals/ 
sürekli gelişim sağlanmış ve sonunda tarım merkezlilikten makine merkezliliğe geçilmeye başlamıştır.

- Toplum 3.0 (Sanayi Toplumu): Avrupa'da Rönesans ve Reform hareketleri sonucunda totaliter yönetimleri, feodal yapıyı ve baskıcı skolastik dünya görüşünü reddeden, burjuvazinin öncülük ettiği bir özgürleşme hareketi olarak ortaya çıkan 'Aydınlanma Çağı'nın getirdiği değişim 18. Yüzyılın üçüncü çeyreğinde İngiltere'de ilk meyvelerini vermeye başlamıştır (Canlığlu, 2008). Freyer (1954)'e göre Sanayi Devrimi 1760'ların ortalarında dokuma endüstrisi ile başlamış, aynı yıllarda James Watt buhar makinesine son şeklini vermiştir. Dokuma dalgasını sırayla demir çelik dalgas1 (1800), ulaştırma dalgası (1825), kimya çağ1 (1850), elektrik endüstrisi dalgası (1900) ve benzin motoru çağı (1900) izlemiştir (Freyer, 1954). Bu süreçte sanayi merkezleri cazibe merkezi haline gelmiş, bu bölgelerde büyük kentler kurulmuş, kent yaşamı benimsenmiş, insanların yaptıkları pek çok ağır işi makinelerin yapmaya başlamasıyla yaşam süreleri uzamış, kalitesi artmış, insan hayatını kolaylaştıran buluşlar toplumsal yaşama yön vermeye başlamıştır.

- Toplum 4.0 (Bilgi Toplumu): Sanayi devrimi ile birlikte makineleşmenin hayatı daha da kolaylaştırdığını, insanoğlunun daha rafine konulara eğildiğinin ayırdına varan sanayi toplumu çalışmalarını daha da ileriye götürdü. Yirminci yüzyılın son çeyreği ile birlikte bilişim teknolojilerinin hızlı penetrasyonu sayesinde bilgi üretimi, bilgi paylaşımı, bilgiye erişim, bilgi pazarlaması gibi kavramlar önem kazanmıştır. Bilgi ile beslenen bu yeni toplum tipinde bilgi hayatın her alanında kullanılan en önemli meta haline gelmiştir. Uçkun vd. (2002), bilgi toplumu kavramını "her türlü bilgiyi üreten, bilgi ağlarına bağlanan, hazır bilgilere erişen, erişilmiş bilgileri kolaylıkla yayabilen ve bu bilgileri her sektörde kullanabilen bir toplum" şeklinde tanımlamaktadır (Uçkun, Uçkun, \& Latif, 2002). Bilgi toplumunda bilişim teknolojilerinin gelişimi sayesinde uluslararası etkileşim yoğunlaşmış, bilgi global anlamda stratejik bir meta haline gelmiş, 'yaşam boyu eğitim' fenomeni ortaya çıkmış, beyin gücü ve nitelikli bireyin değeri artmıştır. Aynı zamanda sanayi toplumunun getirdiği kitle üretim ve tüketim, standartlaşma, kitleselleşme, merkezileşme gibi kavramların yerini bireyselleşme, farklılaşma, yerelleşme, sorgulama gibi kavramlar almıştır. 
Şekil 1: Toplumların Evrimi.

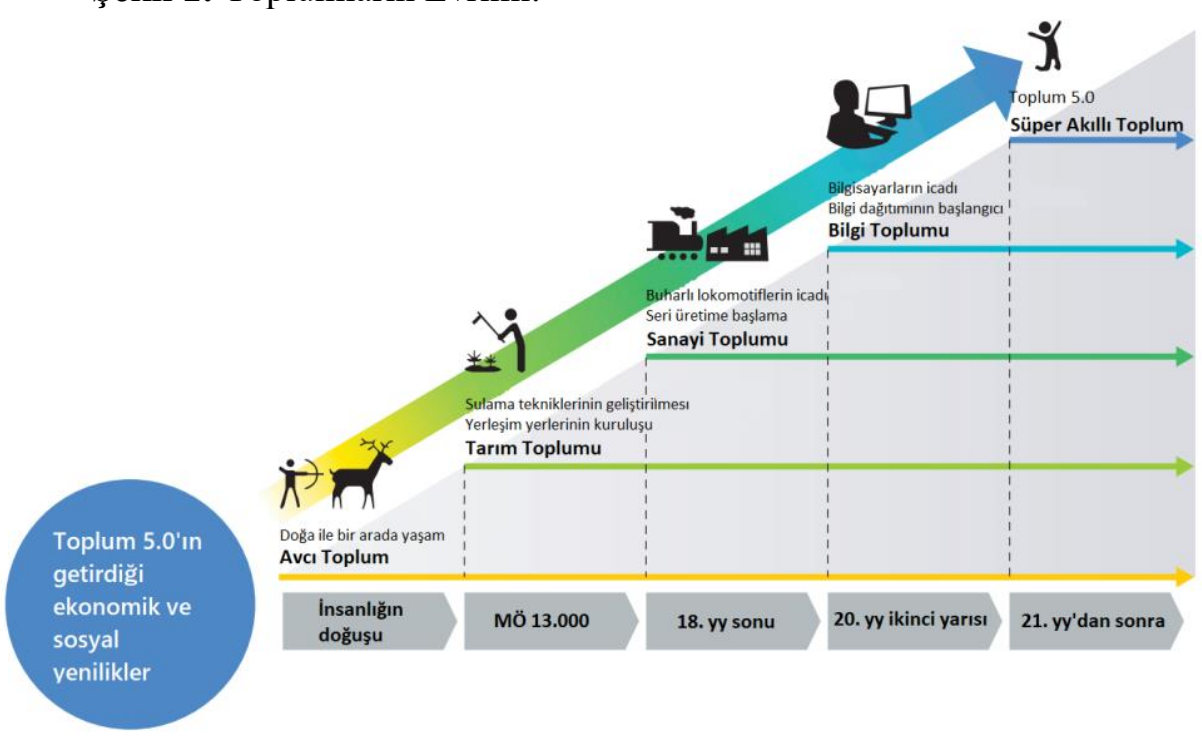

Kaynak: Keidanren (2018). Society 5.0 - CoCreating the Future. Keidanren Policy \& Action. https://www.keidanren.or.jp/en/policy/2018/095_proposal.pdf, Erişim tarihi: (04.08.2020).

\section{DİJITTAL DöNÜŞÜM}

Dijital dönüşümün tanımından bahsetmeden önce bu kavramın sadece bir değişme ya da teknoloji üretme ile ilgili olmadığını belirtmekte fayda bulunmaktadır. Burada öncelikli olarak bilgi ve teknolojinin akıllıca kullanımı sayesinde gerektiğinde kolayca adapte olabilecek değerler, kişiler, optimizasyon becerisi ve örgütsel kapasite geliştirme becerisi söz konusudur. Dijital dönüşüm daha önceki dönemlerde görülen fiziki ve sanayi odaklı üretimin aksine, daha çok bilgi paylaşımına ve iş birliğine dayanan, teknoloji merkezli yüksek katma değer üretmeyi hedefleyen bir yapıya sahiptir (Gözüküçük, 2020). Bu bağlamda dijital dönüşüm, "tüm düzey ve işlevlerdeki dijital teknolojilerin, süreçlerin ve yetkinliklerin aşamalı ve stratejik bir şekilde akıllı entegrasyonu yoluyla bir kuruluşun, endüstrinin veya ekosistemin kültürel, örgütsel ve operasyonel değişimi” olarak tanımlanabilir (iSCOOP, 2020). TÜBITTAK-BİLGEM tarafından oluşturulmuş olan Dijital Akademi adlı portal da dijital dönüşümü "Hızla gelişen bilgi ve iletişim teknolojilerinin sunduğu imkânlar ve değişen toplumsal ihtiyaçlar doğrultusunda organizasyonların daha etkin, verimli hizmet vermek ve faydalanıcı memnuniyeti sağlamak üzere insan, iş süreçleri ve teknoloji unsurlarında gerçekleştirdiği bütüncül dönüşüm" şeklinde tanımlamaktadır. Dijital dönüşüm birkaç teknolojiye indirgenemeyecek kadar geniş kapsamlı ve çok ayaklı bir kavram olsa da öncü teknolojileri Endüstri 
4.0'da da ifade edilen Web 2.0, 3B yazıcılar, dijital medya, büyük veri, yapay zeka, artırılmış gerçeklik, bulut bilişim, nesnelerin interneti ile $5 \mathrm{G}$ ve geniş bant internetin oyunun kurallarını değiştiren etkisi yeni bir dönemin başlamasına öncülük etmiştir. (Dijital Akademi, 2019) Frankiewicz ve Chamorro-Premuzic (2020) de benzer çimde kavramı tanımlarken konunun teknoloji ile değil, beceri ve kapasite ile ilgili olduğunu ifade ederken dijital dönüşüm sürecinde tavsiye niteliğinde odaklanılması gereken beş önemli başlığ 1 şu şekilde sıralamışlardır (Frankiewicz \& ChamorroPremuzic, 2020):

- İnsan öncelikli düşünün: Her ne kadar teknoloji özünde daha az ile daha fazla üretmek amacı güden bir aracı olsa da sadece doğru insan yetenekleri ile etkin kullanılabilir.

- Sosyal becerilere önem verin: Dijital dönüşüm teknolojiden ziyade birey üzerine odaklı olduğuna göre bu dönüşümde teknik becerilerden ziyade sosyal beceriler önem kazanmaktadır.

- Değişimi tepeden başlatın: Yapılan çalışmalar hemen hemen bütün örgütsel değişimlerde yukarıdan aşağ 1 doğru benimsenen yöntemin kabullenme ve hayata geçme süresinin çok daha kısa olduğunu göstermektedir.

- Veri analizleri konusunda dikkatli olun: Her ne kadar son zamanlarda veri alanındaki tartışmalar yapay zekâ, makine öğrenmesi, derin öğrenme veya doğal dil işleme gibi konular üzerine odaklanmış olsa da örgütteki dijital dönüşümün rekabet sağlayıcı faktörü katma değeri yüksek veri elde etmek, bu veriden faydalı çıkarımlar elde etmek ve elde edilen bu çıarımları hayata geçirmektir.

Butler (2020), dijital dönüşümün esasını oluşturan yeni nesil dijital teknolojileri yapay zekâ, blok zincir ve dağıtık hesap sistemleri, kuantum hesaplama, bulut teknolojileri ve nesnelerin interneti olarak tanımlamaktadır (Butler, 2020). Ayrıca artırılmış gerçeklik / sanal gerçeklik, uygulama programlama arayüzleri, büyük veri analitiği de bu listeye eklenebilecek diğer teknolojilerdir.

- Yapay zekâ: Yapay zekâ, doğal sistemlerin yapabildiği her bilişsel faaliyetin yapay sistemlere, daha da yüksek performans düzeylerinde nasıl yaptırılabileceğini inceleyen bilim dalıdır. Yapay zekâ sayesinde aslında insanın yapabileceği etkinlikler daha kısa sürede ve etkin yollarla cansız varlık ve sistemlere yaptırılabilmektedir. İnsanın öğrenim sürecinde bilginin kullanılması örneği gibi makinenin öğreniminde de veriden yararlanılmaktadır (Sarı, 2019). Kategorik olarak yapay zekâ üç seviyede incelenmekte olup içinde bulunduğumuz süreçte görüntü tanıma, tıbbi tanı, chatbotlar, doğal dil işleme gibi işlemlerde kullanılan yapay zekâ dar yapay zekâ olarak adlandırılmaktadır. Bir sonraki seviyede yaygınlaşması beklenen genel yapay zekâ seviyesinde kıyas yaparak problem algılama ve 
karar verme işlemleri yapılabilmektedir. Süper yapay zekâ seviyesinde ise insandan daha yetenekli yapay zekânın üretilmesi öngörülmektedir.

- Blok zinciri: Günümüzde internet pek çok alanda veri transferi için kullanılmaktadır. Blok zincir teknolojisi ise bu verilerin haricinde değer atfedilen varlıkların da transfer edilebilmesini sağlayan dağıtık bir veri tabanı olarak ifade edilebilir. 2008 yılında ortaya çıkan Bitcoin dijital parası ile dünya yeni bir küresel para birimi ile tanışmış oldu. Bitcoin, başlangıçta sadece para olarak kullanılmaktayken, sonradan bu para biriminin dayandığ blok zincir teknolojisinin çok farklı kullanım alanları olduğu ortaya çıkmıştır. Blok zincir, merkezî bir sunucu veya otoritenin ortadan kaldırılmasına olanak sağlayarak güvenin internet ortamında dağıtılması sistemidir. Blok zincir teknolojisi yaygın olarak sanal paraların altındaki teknoloji olarak bilinmekte olsa da sağladığı olanaklar ve çeşitlendirilebilir uygulamalar ile çok geniş kullanım alanına sahiptir (TÜBİTAK BİLGEM, 2017).

- Kuantum hesaplama: Sıradan bilgisayarlar transistörlerin kullanımıyla çalışır. Transistörden geçen bir elektrik akımı bir anahtarı etkinleştirerek anahtarı açar veya kapatır, böylece ona bir veya sıfır değeri verir (Tucker, 2010). Kuantum Hesaplama, yeni bir bilgi işlem paradigmasıdır. Bugün kullandığımız bilgisayarların temeli olan ikili mantıktan farklı çalışır. Günümüzde kullanımda olan bilgi işlem paradigması artık kuantum hesaplamanın aksine klasik hesaplama olarak adlandırılmaktadır. Kuantum hesaplama, ikili mantıksal duruma sahip bitleri kullanmak yerine kübitleri kullanır. Yeni bir hesaplama sistemi geliştirmenin temel motivasyonu, bazı problemlerin kuantum ve klasik hesaplamalarda farklı karmaşıklığa sahip olmasıdır. Bu sistemde bazı zor problemler baş edilebilir hale gelmektedir (Sotelo, 2019).

- Bulut teknolojileri: Bulut bilişim ile ilgili çok sayıda tanım yapılmış olsa da ABD Ulusal Standartlar ve Teknoloji Enstitüsü kavramı "düşük seviyede yönetim çabası ya da hizmet sağlayıcı etkileşimi ile hızlı bir şekilde sağlanıp serbest bırakılabilen bilgisayar ağları, sunucular, depolama, uygulamalar ve servisler gibi ayarlanabilir bilişim kaynaklarının müşterek/ortak havuzuna her yerden, elverişli bir şekilde istenildiğinde ağa erişim sağlayan bir model”" şeklinde tanımlamaktadır. Başka bir ifade ile bulut bilişim, esnek ve dinamik olarak ölçeklenebilir ve yoğun bir şekilde sanallaştırılabilir kaynakların İnternet üzerinden sağlandığı hizmetler olarak yeni bir bilişim türüdür (Turan, 2014).

- Nesnelerin interneti: İnsan müdahalesine veya herhangi bir manuel veri girişine gerek olmaksızın cihazların veya makinelerin belirli bir protokol ile ve tam senkronizasyon halinde kendi aralarında veri iletişimi yaptığı, bilgi topladığı ve toplanan bilgiler ile karar verdiği bir ağ yapısı olarak 
tanımlanmaktadır. Buzdolabının sütün bittiğini tespit ederek otomobilin navigasyonunu en yakın markete yönlendirilmesi ve bu noktada telefonla ödeme yapılabilmesi nesnelerin internetine basit bir örnek teşkil edebilir (Gündüz \& Daş, 2018).

- Artırılmış gerçeklik / sanal gerçeklik: Artırılmış gerçeklik, dijital materyalleri gerçek dünya nesnelerine uyumlandıran teknolojileri ifade etmektedir. Artırılmış gerçeklikte gerçek ve sanal birleştirilerek gerçek zamanlı etkileşim ve üç boyutlu görüntüleme imkânı elde edilmektedir (Azuma, 1997). Öte yandan sanal gerçeklik; yine bir bilgisayara entegre kabin veya gözlük benzeri çeşitli donanımlar sayesinde kullanıcılara kurgulanmış bir ortamda bulunma hissi veren üç boyutlu simülasyon ortamıdır (Kaleci, Tepe, \& Tüzün, 2017). Birbirine benzeyen ve sıklıkla karıştırılan kavramlar olan sanal gerçeklik ile artırılmış gerçekliğin farkı şu şekilde ifade edilebilir; sanal gerçeklik, bilgisayar kaynaklı üç boyutlu ortamlarda karşılaşılan, kullanıcının ortama girdiğinde dünya ile ilişkisinin tamamen yok olduğu bir ortam iken artırılmış gerçeklik gerçek dünya ile bağlantısını devam ettiren, veri ve görüntülerin gerçek dünya görüntülerine eklenebildiği, gerçek ve sanal nesnelerin aynı ortamda birlikte algılanmasını sağlayan bir ortamdır (İçten \& Bal, 2017). Bu iki teknolojinin ötesinde bir diğer kavram da karma gerçeklik olup gerçek ve sanal unsurların gerçek zamanlı olarak etkileşim içerisinde olduğu ortamlar yaratmak amaciyla, gerçek ve sanal dünyaları birleştiren bir artırılmış gerçeklik türevi olarak tanımlanabilir (BIM Teknoloji, 2019). Karma gerçeklik teknolojisinde kullanıcıların artırılmış gerçeklikten farklı olarak fiziksel ortam içerisinde sanal objelerin veya verilerin görselleştirilmesine ek olarak gerçek zamanlı bu sanal objeler ve verilerle ya da başka kullanıcılarla sanal olarak etkileşime girebilmelerine imkân verilmektedir (HoloNext, 2020).

- Uygulama programlama arayüzleri (API): Bir uygulamanın fonksiyonlarına uzaktan erişilerek bu fonksiyonların kullanılmasını sağlayan arayüz olarak ifade edilebilir. API, bir sunucu üzerindeki uygulamaya farklı platformlardan ulaşılmasına olanak sağlamaktadır (Esen, 2018). Örneğin, bir akıllı cihazdaki herhangi bir uygulama kullanıldığında uygulama internete bağlanarak verileri bir sunucuya göndermekte, sunucu bu verileri almakta, yorumlamakta, gerekli işlemleri gerçekleştirmekte ve akıllı cihaza geri göndermektedir. Sonrasında uygulama bu verileri yorumlamakta ve istenen bilgiyi okunabilir bir şekilde kullanıcıya sunmaktadır (İşNet AŞ, 2020).

- Büyük veri analitiği: Günümüz veri analizi araç ve platformları yeni nesil teknolojilerin getirmiş olduğu verileri işlemekte yetersiz kalmaktadır. Dijital dönüşüm sayesinde gerek kamuda gerekse özel sektörde bir anda veri yığınları oluşmuş durumda olup sosyal medyada her saniye milyonlarca 
işlem yapılmaktadır. Yaygınlaşan nesnelerin interneti ile birlikte bağlı cihazlar sürekli veri yollamakta, taşıtlar GPS sinyalleri göndermekte, dijital platformlarda içerikler sunulmakta, tüketilmekte, makineler iş kaydı tutmaktadır. Dolayısıyla bütün bu büyük hacimli işlemler geleneksel veri analitiğini yetersiz kılmaktadır. En az hacimsel büyüme kadar önemli olan bir diğer değişken de verilerin niteliğidir. Sayılmış olan araç ve platformların her birinin üretmekte olduğu verinin türü farklı olup alışık olduğumuz yöntemlerin bu farklı nitelikteki veriyi aynı potada eritme becerisi mevcut değildir. Ayrıca sayılmış olan söz konusu veriler statik değil, dinamik yapıda olup anlık analize ihtiyaç duyulmaktadır. Dolayısıyla yeni nesil veri analitiği alanı daha kapsamlı araç, algoritma ve platformlara ihtiyaç duymuş, bu ihtiyaçtan da büyük veri kavramı ortaya çıkmıştır.

Burada dijital dönüşüm kavramından bahsedilmesinin nedeni bilgi-yoğun yapılandırılmış toplumsal yapıya geçiş olarak ifade edilebilen Toplum 5.0 inisiyatifinin temelinde bir dijital dönüşüm fikrinin bulunması ve bu dönüşümün de büyük ölçüde sosyal / örgütsel / zihinsel bir değişime işaret ediyor olmasıdır.

\section{TOPLUM 5.0'IN UNSURLARI}

Toplum 5.0 inisiyatifinin en önemli vaadi endüstriler kadar bireysel yaşamları da dönüştürmektir. Söz konusu dönüşümü ekolojik biçimde gerçekleştirmeyi amaçlayan girişim, bu bağlamda merkezine Birleşmiş Milletler Sürdürülebilir Kalkınma Amaçlarını almış olup bu dönüşümü on temel başlıkta ele almaktadır $^{4}$ (Keidanren, 2018).

- Şehirler ve Bölgeler (Sağlık ve Kaliteli Yaşam, Nitelikli Eğitim, Toplumsal Cinsiyet Eşitliği, Temiz Su ve Sanitasyon, İnsana Yakışır İş ve Ekonomik Büyüme, Sürdürülebilir Şehirler / Topluluklar, Sorumlu Üretim / Tüketim, İklim Eylemi): Farklı yaşam biçimlerinin ve iş yapış tarzlarının desteklenmesi adına Toplum 5.0 girişimi öncelikle kırsal ve kentsel yaşamın çeşitlendirilmesini ve her biri için cazibe merkezleri yaratılarak altyapı sorunu bulunan bölgeler dahil her yerde yaşam kalitesinin artırılmasını öngörmektedir. Gerek farklı yaşam biçimlerinin desteklenmesi gerekse ekolojik olması bakımından otonom sistemlerin yaygınlaştırılması en önemli önceliklerdendir. Nerede olursa olsun yüksek standarda sahip sağlık hizmetleri ve eğitime dünyanın her yerinden erişim bir diğer önem arz eden konudur. Özellikle ileri yaşta ya da dezavantajlı gruplarda bulunan bireylerin yaşam standartlarının artırılması amacıyla daha önce bahsedilen otonom sistemlerin bu kişilerin hizmetine sunulması öngörülmektedir. Söz konusu gelişmelerin yaşam ve çalışma seçeneklerini artırması, farklı yaşam

\footnotetext{
${ }^{4}$ Her bir başlığın Birleşmiş Milletler Sürdürülebilir Kalkınma Amaçlarında desteklediği / atıfta bulunduğu alanlar başlık yanında parantez içinde belirtilmiştir.
} 
biçimlerinin meydana gelmesini ve bu yaşam biçimlerine saygı duyan bir toplum modelini mümkün kılması beklenmektedir.

- Enerji (Erişilebilir ve Temiz Enerji, Sanayi Yenilikçilik ve Altyapı, İklim Eylemi): Enerji bağlamında akıllı şehirler ve topluluklar için enerji elde etme ve tüketme biçimlerinde değişiklik yapılması söz konusudur. Veriye dayalı enerji ağları oluşturularak daha efektif enerji kullanımının sağlanması, bunun da yenilenebilir kaynakların daha yoğun kullanımıyla elde edilmesi amaçlanmaktadır. Dağıtık enerji üretimi ile güç depolama sistemleri ve talep kontrollerini entegre etmeyi amaçlayan enerji ağ sistemleri sayesinde maliyetlerin düşmesi, daha güvenilir ve sürdürülebilir enerjiye herkesin ulaşması sağlanacaktır.

- Afet Önleme ve Azaltma (Sağlık ve Kaliteli Yaşam, Temiz Su ve Sanitasyon, Sürdürülebilir Şehirler / Topluluklar, İklim Eylemi): Dünya çapında doğal afetler yoğunlaşmakta, yaygınlaşmakta ve daha etkin önlemlerin alınması kaçınılmaz hale gelmektedir. Toplum 5.0 girişiminde tahliye merkezlerinden, IoT ekipmanlarından ve sosyal medyadan hasar ve kurtarma ile ilgili veriler toplanarak bunların kamusal ve sektörel paydaşlarla paylaşılıp afet durumunda hızlı müdahalenin kolaylaştırılması için afet bilgi iş birliği sistemlerinin inşa edilmesi öngörülmektedir. $\mathrm{Bu}$ konuda çokça bahsi geçen dağıtık sistemler arasında en önemli unsurların başında sayılabilecek olan dağıtık enerji sistemleri sayesinde olası afetlerde risk azaltılarak sürdürülebilir bir sistem kurulacaktır.

- Sağlık Hizmetleri (Sağlık ve Kaliteli Yaşam): Muayene / tedavi, ilaç ve bakım unsurlarını içeren ömür boyu sağlık hizmeti sunulması ile sağlık sektöründe radikal bir dönüşüm planlanmaktadır. $\mathrm{Bu}$ süreçte tıbbi teknolojilerin bizlere sunmuş olduğu yeni nesil araç ve yöntemlerin kullanılması en önemli enstrümanlardan biri olacaktır. Geleneksel tıp yaklaşımları benzer kişilerde ortaya çıkan hastalık ve semptomlar için benzer tedavi yaklaşımları öngörürken Toplum 5.0 ile gelen yeni yaklaşımlar kişiye özel teşhis ve tedavi süreçleri sayesinde henüz önleyici aşamada hastalığın ilerlemesini ve şiddetlenmesini engelleyecektir. Giyilebilir teknolojiler, yeni nesil yüksek hızlı iletişim ağları ve yapay zekâ tabanlı yaşam destek hizmetleri sayesinde bireyler mekân bağımsız bir şekilde sürekli veri takibi ile kendi sağl1klarını kontrol altında tutabilecek, daha uzun ve kaliteli bir yaşam sürebileceklerdir.

- Tarım ve Gıda (Açlığa Son, Sorumlu Üretim / Tüketim, Sudaki Yaşam, Karasal Yaşam): Tarım sektöründe günümüz gelişmiş ekonomilerinde halen kullanılmakta olan yapay zekâ tabanlı uzaktan izleme ve kontrol, tarım robotları, otonom kara ve hava araçları gibi yeni nesil teknolojilerin kullanımının yaygınlaşması planlanmaktadır. Bu sayede çalışma saatlerinin 
azaltılarak maksimum verimin elde edilmesi amaçlanmaktadır. Ayrıca çevreyle barışık biçimde biyolojik çeşitliliğin artırılması hedeflenmektedir.

Bu bağlamda üretim, işleme, lojistik, satış ve ihracat kalemlerinin entegre edildiği Gıda Değer Zincirinin veri ve veri analizi teknolojileri sayesinde optimizasyonunun da sağlanması düşünülmektedir.

Gıda değer zincirinde oyuncuların çeşitlendirilmesi ve teknolojik inovasyon sayesinde tarımın çok cazip hale gelecek olması ile Toplum 5.0'ın öngördüğü dağıtık toplulukların çekirdeğini oluşturacak olan gençler için tersine göçün bir firsat haline gelmesi çok muhtemeldir.

- Lojistik (Sürdürülebilir Şehirler / Topluluklar, Sorumlu Üretim / Tüketim): Lojistik, tedarik zinciri boyunca ürün akışını sağlamak suretiyle ekonomik büyümede önemli bir rol oynar ve iş faaliyetleri ile günlük yaşamı destekleyen sosyal altyapının önemli bir parçasını oluşturur. Özellikle son yıllarda e-ticaretin hızlı büyümesi ve tedarik zincirlerinin küreselleşmesi Toplum 5.0'da daha da çeşitli, kapsamlı ve komplike bir lojistik sistemini gerektirmektedir.

Kargoların ve ulaşım araçlarının gerçek zamanlı lojistik izleme ve kontrol sağlamak için IoT teknolojileri kullanarak ağlara bağlanması, ilgili oyuncuların, tedarik, üretim, nakliye ve satış ile ilgili verileri gerçek zamanlı platformlarda paylaşmaları, arz ve talebi tahmin etmek için yapay zekâ kullanarak tüm tedarik zincirlerini koordine ve optimize etmeleri olanaklı hale gelmektedir.

Ayrıca süreçlerde insan gücünü minimum seviyeye indirmek için otonom sürüş, insansız hava araçları (drone) ve robotlarla ikame edilebilen işlerin çoğunun otomatikleştirilmesi öngörülmektedir. Bu tür gelişmeler kırsal, dağllk ve uzak bölgelerde verimli ve hızlı hizmetler sağlarken, kentsel bölgelerde büyük lojistik hacimlerin kolayca yönetilmesini sağlayacaktır.

- Üretim ve Hizmetler (Toplumsal Cinsiyet Eşitliği, İnsana Yakışır İş ve Ekonomik Büyüme, Sanayi Yenilikçilik ve Altyapı): Yeteneklerin yapay zekâ temelli dağıtımı üretim ve hizmet sunumu için güçlü araçlar sağlamaktadır. Şimdiye kadar verileri analiz etmek, kullanışlı mal ve hizmetler yaratmak için büyük miktarda Ar-Ge yatırımı ve profesyonel bilgi gerekiyordu. Dijital dönüşüm sayesinde, bu yetenekler dağıtılarak yapay zekâ modülleri ve hizmetleri olarak kullanılabilir hale gelmektedir. Bütün bu dönüşümler daha yüksek kaliteli mal ve hizmetlerin hızlı bir şekilde oluşturulmasını ve sunulmasını sağlamaktadır.

Bireysel tüketicilerin zevklerini açı bir şekilde yansıtan gıda, giyim, barınma ve eğlenceyle ilgili ürünler bu hususta bir örnek teşkil edebilir: Geleneksel üretim yöntemlerinin tersine tüketicilerin kolayca ve uygun 
fiyatla üç boyutlu yazıcıları kullanarak kendi zevklerine uygun tasarım, malzeme, renk, desen ve boyutta eşi benzeri olmayan ürünler yaratmalarını sağlayacak üretim sistemlerin kurulması olasıdır. Açık kaynaklı, dağıtık dijital devre ve sensörlerin kullanımı yaygınlaştıkça çeşitli hizmetlerin ve donanımların sisteme entegrasyonu da hizlanacaktır.

İş modelleri donanıma değil, hizmetlere dayalı olacaktır. Farklı değer biçimleri sunan dijital dönüşümün bir parçası olarak daha fazla insan üretim ve hizmet sunumuna kat1labilecektir.

- Finans (Yoksulluğa Son, Toplumsal Cinsiyet Eşitliği, İnsana Yakışır İş ve Ekonomik Büyüme, Sanayi Yenilikçilik ve Altyapı): Dijital dönüşüm ödeme, finansman, sigorta ve varlık oluşturma dahil olmak üzere çok çeşitli ve kişiye özel finansal hizmetleri kullanıma sunacaktır.

Düşük maliyetli, uygun, hızlı, güvenilir ve çeşitlendirilmiş çözüm yöntemleri bireylerin her yerde nakit para bulundurma zorunluluğu olmaksızın yaşamalarını sağlayacaktır. Çeşitli hizmetleri ve akıllı sözleşmeleri birbirine bağlayan uygulamalar yeni hizmetlerin oluşturulmasını kolaylaştıracaktır. Ortalama insan ömrünün 100 yıla eriştiği bir çağda bu tür hizmetler kişiye özel gelişmiş akıllı varlık yönetimi ve sigorta optimizasyonu yoluyla hastalık, yaralanma ve kaza risklerini azaltmak suretiyle bireysel yaşam tarzlarına uygun istikrarlı varlık oluşumuna yardımci olacaktır. Yeni nesil endüstriler ve piyasadaki diğer paydaşlar için gerekli fonlar sağlanacak ve finansal sistemler fonların toplum genelinde daha verimli ve etkili bir şekilde kullanılması için daha istikrarlı hale gelecektir.

Küresel bir bakış açısıyla finansal hizmetlere erişimin iyileştirilmesi adına yaygınlaşması en önemli teknolojilerden biri de blok zincir teknolojisi olup bu süreçte diğer yeniliklere dayanan kripto para birimleri yeni değer değişim biçimleri yaratarak bugüne kadar olmayan bir üretim ve ekonomi sistemini mümkün kılacaktır. Güvenli, akıllı ve izlenebilir küresel sözleşme ve uzlaştırma sistemlerinin kurulması ile çok çeşitli üretim ve hizmet sunumu için bir temel oluşturarak farklı bireylerin küresel ölçekte bir dizi üretim ve hizmeti genişletmesine olanak tanıması beklenmektedir.

- Kamu Hizmeti (Yoksulluğa Son, Sağlik ve Kaliteli Yaşam, Nitelikli Eğitim, Eşitsizliklerin Azaltılması, Barış Adalet / Güçlü Kurumlar): Toplum 5.0 girişimi radikal bir toplumsal dönüşümü öngördüğüne göre bu süreçte en önemli dönüşüm ayağının kamusal alanda gerçekleşeceğini ifade etmek yanlış olmayacaktır. Merkezî ve yerel yönetimler sistemlerini dijitalleşmeye dayalı olarak yeniden inşa ederek başlayacaklardır. Görevlerin çoğunun dijitalleştirilerek farklı aktörler arasında verilerin hızla paylaşılması, daha yaratıcı kamu hizmetleri sağlamalarını gerektirecektir. Örneğin demografik 
analizler ve çeşitli kaynaklardan elde edilen veriler yoluyla kreşler, okullar, hastaneler ve huzurevleri için kesin talep tahmini yapılması ile kamu kurumlarının zamanında ve uygun şartlarda hazırlıkların yapılmasını ve gerekli hizmetlerin yeterli biçimde ve zamanında sunulmasını sağlayacaktır. Yaygın biçimde kurulan güvenlik ağları sayesinde herkesin güvenle çeşitli zorlukların üstesinden gelmesi sağlanacaktır.

- İş birliği (Amaçlar İçin Ortaklıklar): Toplum 5.0 inisiyatifi tek bir ülke ya firmanın gerçekleştirebileceği bir girişim değildir, bireysel ve kurumsal bazda herkesin katkı sunacağ 1 geniş katılımlı bir iş birliği gerektirmektedir. $\mathrm{Bu}$ girişimin yaratıcısı Japonya tüm dünyadaki paydaşlarla ortaklaşa bu konsepti hayata geçirmek istemektedir. Süreçte kazanılan problem çözme bilgi birikim ve tecrübeyi paylaşarak sürdürülebilir küresel kalkınmaya katkıda bulunmanın en önemli misyon olduğu düşünülmektedir.

\section{TOPLUM 5.0'IN BEKLENEN SONUÇLARI}

İnsanlar Toplum 5.0 inisiyatifinin öngördüğü gelişmiş yeteneklere ulaşıp tanıdıkça önceki toplum yapıları ile üstesinden gelinemeyecek çeşitli kısıtlılıklardan kurtulacak ve farklı yaşam tarzları sayesinde topluma katkı sağlama firsat ve özgürlügüne sahip olacaklardır. Bu bağlamda söz konusu felsefenin toplumu dönüştürürken gerçekleştirmeyi vadettiği kitlesel geçişler aşağıdaki gibi ifade edilebilir (Keidanren, 2018).

- Verim odakl11ıktan değer yaratan topluma geçiş: Üçüncü ve dördüncü nesil toplumlar (sanayi ve bilgi toplumları) büyüyen nüfuslarına maddî zenginlik oluşturmak amaciyla seri üretim ve tüketim yoluyla ölçek ve verimlilik peşinde koşarak büyük ölçüde kitlesellik kavramını baskın kılmışlardır. Bu tür toplumlarda, geleneksel kurallara ve planlara uymanın ve bir planlauygula-kontrol et-harekete geç döngüsünü takip etmenin son derece önemli olduğu düşünülmekteydi. Mallar ve hizmetler tek tipti ve verimlilik arayışında benzer şeylere standartlaştırılmış süreçler uygulandı. Oysa Toplum 5.0'da ihtiyaçlar daha çeşitli hale gelmekte ve üreticiler söz konusu ihtiyaçları dijital teknolojilerle tedarik etmeye hazır hale gelmektedirler. $\mathrm{Bu}$ süreçte insanlar verimliliğe odaklanmaktan kurtulmalı ve bireysel ihtiyaçların karşılanmasına, sorunların çözülmesine ve değer yaratılmasına önem vermelidirler.

- Tek tip toplumdan bireysel yeteneklerden faydalanmaya geçiş: Özellikle sanayi toplumunun yaygın dayatması sonucu insanların standartlaştırılmış süreçlere uygun biçimde tek tip mal ve hizmetleri kabul etmeleri ve tek tip yaşam sürmeleri gerekmekteydi. Toplum 5.0, insanların toplumdaki çeşitli ihtiyaçları ve zorlukları belirlemek ve bunları gerçek işe dönüştürmek için hayal gücüne sahip olmasını gerektirmektedir. Farklı insanlar, toplumdaki farklı değerleri takip etmek için çeşitli yetenekler kullanmalıdırlar. İnsanlar 
cinsiyet, ırk, milliyet vb. ayrımcılık, düşünme biçimleri ve değer yargıları yoluyla yabancılaşma gibi bireyselliğin baskılanmasından uzak yaşamalı, öğrenmeli ve çalışabilmelidir.

- Toplumsal eşitsizlikten firsatlar toplumuna geçiş: Günümüz toplumunun en büyük sorunlarından biri bilgi ve zenginliğin kısıtlı sayıda kişide toplanmış olması, dolayısıyla gelir adaletsizliğidir. Oysa Toplum 5.0 öğretisinde zenginlik ve bilgi topluma yayılmalı ve ademi merkeziyetçi bir anlayışla dağıtık hale getirilmeli, sosyoekonomik oyuncular rolleri yatay olarak paylaşmalı, zenginliğin ve bilginin yoğunlaşmaması sağlanmalıdır. $\mathrm{Bu}$ sayede yoksul toplumlarda veya ücra bölgelerde doğan çocuklar için de eğitim, sağlık ve çalışma firsatları garanti altına alınabilir.

- Kaygidan toplumsal huzura geçiş: Önceki toplumlarla birlikte hızla ve büyük miktarlarda gelişen altyapının bozulması, deprem ve sellerin neden olduğu ciddi hasar, artan eşitsizlikle bağlantılı olarak kamu güvenliğinin bozulması, terörizm ve diğer krizlere ilişkin artan sosyal kaygı ile siber saldırıların neden olduğu hasarlar gibi toplumsal huzursuzluğa neden olan hassasiyetler ortaya çıktı.

- Buna karşın Toplum 5.0 yeni, çeşitlendirilmiş ve dağıtık bir sosyal altyapı ile sosyal esnekliği artıran (kırılganlığı azaltan) ve sürdürülebilir kalkınmayı mümkün k1lan bir yapı öngörmektedir. Buna göre toplum endişeden kurtulacak ve güven içinde yaşayacaktır. Özellikle fiziksel anlamda terörizme ve afetlerle siber saldırılara karşı direnç artırılacak, güvenlik ağları güçlendirilecektir. Yüksek düzeyde tıbbi bakım, konumdan bağımsız olarak erişilebilir hale gelecektir. Huzurlu ve güven içinde yaşayan özgür bir toplumun temelleri bu şekilde atılacaktır.

- Ekolojik kısıtlanmalardan doğa ile uyum içinde bir topluma geçiş: Özellikle sanayi toplumu kitlesel kaynak tüketimine dayalı, çevresel etkisi yüksek modeller üzerine kurulmuştur. Toplum 5.0'1n en önemli sonuçlarından biri yenilenebilir enerji ve dağıtık enerji ağları sayesinde sürdürülebilirliği ve ekolojik üretimi devreye alıyor olmasıdır. Paylaşım ekonomisi ve şeffaflık / hesap verebilirlik arttıkça temiz suya erişim, etkin atık yönetimi ile çevre ve sağlık için daha faydalı gıdalara olan ilgi artacak, gıda israfı da keskin bir şekilde azalacaktır.

Değer yaratma, çeşitlilik, ademi merkeziyetçilik, esneklik / sürdürülebilirlik ve çevresel uyum, yaşamın ve doğanın niteliklerini somutlaştıran olgular olarak siralanabilir. Toplum 5.0 felsefesinin en önemli vaatleri olarak da adlandırılabilecek bu geçişler önerilen radikal toplumsal dönüşümde hızlı ilerlemeyi sağlayacak, bu ilerlemede yol gösterici olacaktır. 
Arl, E. S.

DEÜ SBE Dergisi, Cilt: 23, Sayl: 1

\section{DÜNYADAN TOPLUM 5.0 ÖRNEKLERİ}

Tartışılmasının, kavramsallaşmasının ve ilk tanıtımının üzerinden çok uzun süre geçmemiş olmasına rağmen Toplum 5.0 gerek literatürde ${ }^{5}$ gerekse uygulamada üzerinde çokça ve artarak konuşulan bir konu haline gelmiştir. Önemli bir kısmı Japonya'dan olmak üzere dünyanın çeşitli yerlerinden Toplum 5.0 uygulama örnekleri mevcuttur.

Toplumun genel huzuru ve refahı ile yaşam kalitesini yükseltmeyi hedefleyen Toplum 5.0 kapsamında öngörülen önemli uygulamalardan biri global bir gerçeklik olan doğal afetlerin önlenmesi ve erken koruyucu müdahalelerin yapılması üzerinedir. Bu bağlamda afetlerden etkilenen alanların uydulardan, hava denetim radarlarından veya insansız hava araçlarından (drone) ya da sensör verilerine dayalı hasar bilgilerinden ve otomobillerden alınan yol hasarı bilgilerinden elde edilen verilerin büyük veri platformlarında yapay zekâ tabanlı analizleri yoluyla anında müdahale edilmesi mümkündür. Bu sayede afetlerden etkilenenlerin yerleri anında tespit edilerek sağlık, gıda, hijyen ve barınma ihtiyaçları hızlı bir şekilde giderilebilmekte, kurtarma robotları kullanımı ile enkazlar daha güvenli biçimde taranabilmekte, yollar kapandığı takdirde malzeme lojistiği insansız hava araçları (drone) ile sağlanabilmektedir (Cabinet Office, Government of Japan, 2018).

Menşe ülkesi olması itibarı ile "insan merkezli" Toplum 5.0 projesi kapsamında Japonya'da 157 bölgede kamu-özel-akademi ortaklığında toplam 229 adet akıllı şehir projesi faaliyete geçirilmiştir. Örneğin yüksek araç sahipliği ile birlikte toplu taşıma seçeneklerinin zayıf olduğu Maebashi şehrinde nüfusun yaklaşık \%30'u 65 yaş ve üzerindedir ve bireysel araç kullanmaları sakıncalıdır. Söz konusu inisiyatif kapsamında sürücüsüz toplu taşıma araçlarının diğer akıllı şehir ağına entegre edilmesiyle Maebashi ulaşım alanında gerçekleştirilen projelerin pilot merkezi olmuştur. Aynı amaç doğrultusunda yapılan protokoller sayesinde ABD ile Japonya' daki 455 şehir diplomatik kardeş şehirler ilan edilerek ortak projelerin önü açılmıştır. Maebashi ile Alabama eyaletine bağlı Birmingham şehri arasında bu şekilde gerçekleşen bir protokol sayesinde Birmingham'ın mevcut ulaşımı insan merkezli çözümlerle iyileştirilmiş, Toplum 5.0'1n benimsenmesiyle şehirlerin siber ve fiziksel alanlarının etkileşime girdiği ve nihayetinde sakinler için yaşam kalitesini artıran platformlar ortaya konmuştur (Deguchi, 2020). Şehirleşme ve altyapıya yönelik bir diğer uygulama da yine Japonya'da özellikle büyüme döneminde kamusal altyapıda meydana gelen bozulmalardaki bakım ve denetimin bütçede

\footnotetext{
${ }^{5}$ Web of Science Core Collection'da Toplum 5.0 konusunu ele alan 2016'da 1, 2017'de 5, 2018'de 7, 2019'da 18 ve 2020'de 20 adet; Scopus veritabanında ise 2017'de 7, 2018'de 14,2019 'da 37 ve 2020 'de 58 adet kayıt bulunmaktadır. Ayrica Dergipark sisteminde 2018 'de 1, 2019'da 2 ve Aralık ayı hariç 2020 'de 7 adet olmak üzere toplam 10 adet çalışma mevcuttur.
} 
büyük mali yük teşkil etmesine yönelik olarak meydana gelmiştir. Bu sorunu çözmek amacıyla yolları, köprüleri, barajları ve tünelleri denetlemek için sensörler, yapay zekâ ve robotlar kullanılmış, onarım gerektiren yerlerde erken tespit ve teşhis yapılarak beklenmedik kazalar en aza indirilmiş, onarım için harcanan süre azaltılmış, maliyetler düşürülmüş, güvenlik ve üretkenlik artmıştır (Kent, 2019).

Söz konusu uygulamaların çalışma alanı bulduğu en önemli sektörlerden biri de sağlık sektörüdür. Toplum 5.0 ile birlikte yaşam kalitesini artırmak adına hastadoktor-makine iş birliğini ortaya koyan "akıllı sağlık" kavramı ortaya çıkmıştır. Bu kavram kendini kimi zaman mobil uygulamalarla, kimi zaman da giyilebilir teknolojilerle göstermektedir. Yüzük, saat, bileklik ya da ceket gibi günlük aksesuar / kıyafet biçiminde tasarlanmış olan giyilebilir teknoloji ürünlerinde bulunan hassas sensörler kablosuz olarak bilgisayar ya da mobil cihazlarla senkronize biçimde çalışmakta, anlık sağlık verilerini (adım, kalori, nabız, beslenme, vs.) göstermekte, gerektiğinde ağın bir diğer paydaşı olan sağlı kuruluşu ya da hekime de anlık veri sağlamaktadır (İTÜNOVA Teknoloji Transfer Ofisi, 2017; Perry, 2016; Healio, 2017; Wise, 2018; Erkılıç \& Yalçın, 2020). Bu teknolojiler sayesinde uzaktan bakım hizmetleri yaygınlaşmakta, hastaların tedavi süreçlerine katkıları sağlanmakta, erken teşhisin önü açılmakta, yerinde tedaviye imkân vererek sağlik kuruluşlarının da yükü hafifletilmekte, farklı sağlık kuruluşlarında dağınık halde bulunan hasta verileri birleştirilerek paylaşılmakta ve veriye dayalı etkin tedavi yöntemleri geliştirilmektedir (Kent, 2019). Yeni nesil teknolojilerin en etkili ürünlerinden olan yapay zekânın bu alanda kullanımı da oldukça yaygındır. Örneğin İngiltere'de sağlık hizmetleri veren Babylon Health isimli kuruluş yapay zekâ temelli çalışan sohbet botu sayesinde dijital bir hekim oluşturmuş ve mobil uygulama aracılığıyla hastaların bu hekimle çok kısa sürede doğrudan etkileşime girmelerini sağlamıştır. Benzer biçimde merkezi Hong Kong'da bulunan Insilico Medicine isimli biyoteknoloji firması yaşam kalitesi odaklı çalışmaları neticesinde yapay zekâ kullanarak daha az yan etkiye sahip ilaçlar tasarlamak amaciyla Oxford Üniversitesinden bir ekiple ortak çalışmalara başlamışlardır (Büyükgöze \& Dereli, 2019).

Finans piyasalarında, özellikle bankacılık işlemlerinde finansal teknoloji firmalarına ve bankalara açık biçimde uygulama programlama ara yüzlerini (API) tanıtarak blok zinciri teknolojisi kullanımıyla nakit kullanımı minimum düzeye indirilmekte, bankacılık işlemleriyle geçen zamandan ve bu işler için ödenen komisyonlardan tasarruf edilmektedir (Kent, 2019).

Toplum 5.0'ın tarım ve gıda vizyonu bağlamında da pek çok uygulama mevcuttur. Sensör teknolojisi ve nesnelerin interneti sayesinde meteorolojik veriler, ürün büyüme verileri ile piyasa verileri, gıda eğilimleri gibi bilgilerden oluşan büyük veri niteliğindeki verilerin yapay zekâ ile analiz edilmesi sonucu pek çok işlemde yüksek verim sağlanmaktadır. Örneğin tarım işlerini sürücüsüz traktörler aracılığıyla iş gücünden tasarruf ederek, insansız hava araçları (drone) aracılığıyla mahsul 
verilerinin toplanmasını otomatikleştirerek ve hava tahmini, su verileri vb. dayalı olarak su yönetimini optimize ederek emek tasarrufu sağlayan ve yüksek verim sağlayan, ürünleri tüketicilere istendiği zamanda ulaştırarak değer zincirini güçlendiren "akıllı tarım" uygulamaları son dönemde oldukça yaygınlaşmıştır. $\mathrm{Bu}$ uygulamaların verimlilik sağlamak dışında sürdürülebilir kalkınma amaçları bağlamında bir diğer önemi de bu çözümlerin gıda üretimini artırmaya ve arzı dengelemeye, tarımsal bölgelerdeki işsizlik sorununu çözmeye, gıda israfını azaltmaya ve tüketimi canlandırmaya aday olmasıdır (Cabinet Office, Government of Japan, 2018). Söz konusu ürünler tüketicilere ulaşmadan önce olduğu gibi ulaşırken de Toplum 5.0 sayesinde makro amaçları yerine getirmeyi amaçlamaktadır. Yeni nesil teknolojilerin sunduğu hizmetler sayesinde tüketicilere alerji bilgilerine ve kişisel tercihlerine göre özelleştirilmiş ürün önerileri sunulmakta, saklama alanlarında depolanan yiyeceklerin yönetimi otomatikleştirilerek yalnızca ihtiyaç duyulan ürünlerin siparişi ile israf azaltılmakta, sağlık koşullarına göre pişirme önerileri sunulmakta, bu sayede gida toplumsal amaçlara ulaşılırken gida endüstrisi de daha rekabetçi hale getirilmeye çalışılmaktadır (Cabinet Office, Government of Japan, 2018).

\section{TÜRKIYY'NIN TOPLUM 5.0 ENTEGRASYONU}

Türkiye pratiğine bakıldığında durum bir parça iç karartıcı olsa da gösterilecek irade sonucu yapılması gereken işler, atılması gereken adımlarla planlı ve çok çalışma sayesinde hâlen fazlaca açılmış olan makası kapamanın mümkün olduğu söylenebilir. Öyle ki, gelişmiş batı dünyası ile Japonya, Kore, Singapur gibi Asya ülkeleri söz konusu inisiyatiflere global anlamda öncülük edip her biri kendi parametreleri dahilinde girişimlerde bulunurken bu girişimlerden belki de son zamanlarda en fazla konuşulanı Endüstri 4.0 ile ilgili 2016 yllında ülkemizde yürütülen bir çalışmada firmaların konuyla ilgili bilgi düzeylerinin son derece düşük olduğu ortaya çıkarken sanayimizin dijital olgunluk seviyesinin dört bölmeli skalada ise Endüstri 2.0 ile Endüstri 3.0 arasında (tam olarak 2.6) olduğu gözlemlenmiştir (TÜBİTAK, 2016). Daha da açıklayıcı bir ifade ile söz konusu skala üzerinde elektrik çağını kapatıp bilgisayar çağının henüz başlarında olan bir sektör / ekonomi için yapay zekâ, nesnelerin interneti, büyük veri, simülasyon, siber fiziksel sistemler, robotik, vs. kavramların içselleştirilmesi hiç de kolay değildir.

Konuyla ilgili üzerinde en fazla tartışılan alanlardan biri de Endüstri 4.0 ile birlikte büyük ölçüde insanların yapmakta olduğu işlerin robotlara bırakılmasının zaten sorunlu bir alan olarak karşımızda durmakta olan istihdam üzerine yapacağ etkilerdir. Zira özellikle genç işsizliğinin oldukça yüksek olduğu Türkiye'de mevcut beden gücüne dayalı işleri de kaybetmek pek çok kişi için tahammül sınırlarını aşabilecek sonuçlar öngörmektedir. Öncelikle Türkiye'de göreceli işgücü maliyetlerinin düşük oluşu ve son yıllarda değişen demografik yapıyla birlikte bu düşüşün daha da artması, ayrıca ülkenin jeopolitik konumu bakımından incelendiğinde kısa vadede ciddi bir tehdit görünmese de bu geçişin kaçınılmaz 
olduğu bilinmeli ve istihdam alanlarını kademeli olarak bedensel işgücüne dayalı alanlardan beyin gücüne dayalı (bilgi, karar verme, yönetme, uygulama geliştirme, yaratıc1lık) alanlara kaydıracak makro politikalar geliştirilmelidir (Taş, 2018).

Benzer biçimde Bilim, Sanayi ve Teknoloji Bakanlığının 2019 yılında yürütmüş olduğu bir başka çalışmada yer alan, 20 ve üzeri sayıda çalışanı bulunan sanayi işletmelerinin yeni nesil teknolojilerden haberdar olma durumu aşağıdaki grafikte verilmektedir:

Şekil 2 İşletmelerin Endüstri 4.0'a İlişkin Teknolojilerden Haberdar Olma Durumu.

\section{İşletmelerin Endüstri 4.0'a İlişkin Teknolojilerden Haberdar Olma Durumu}

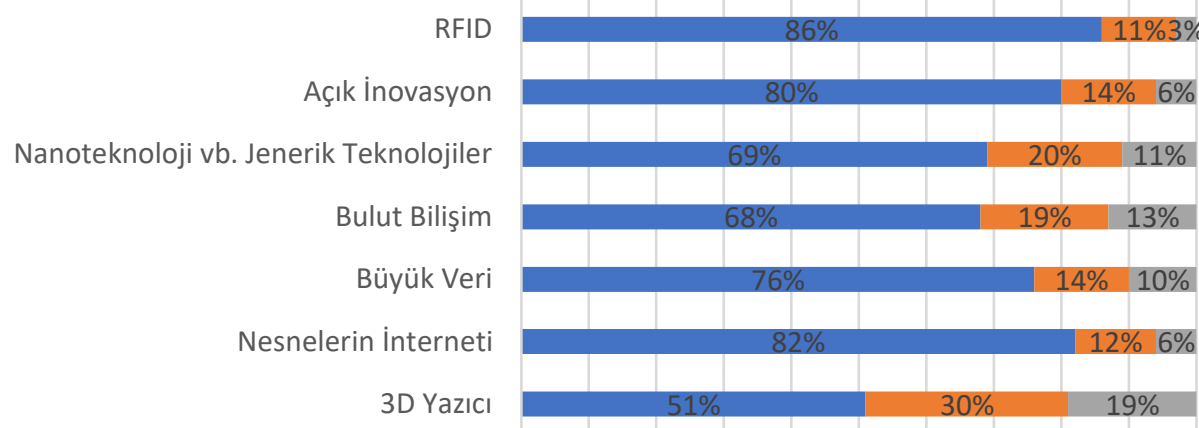

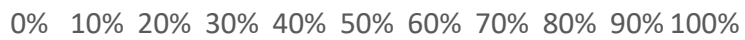

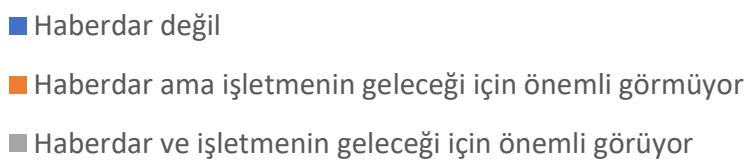

Kaynak: Bilim Sanayi ve Teknoloji Bakanlı̆̆ (2019). Türkiye'nin Sanayi Devrimi: Dijital Türkiye Yol Haritası. https://www.gmka.gov.tr/dokumanlar/yayinlar/2023_DijitalTurkiye-Yol-Haritasi.pdf, (Erişim tarihi: 28.07.2020).

Görüldüğü gibi ilgili kuruluşların çok ciddi bir bölümü söz konusu teknolojilerden ya bihaber durumda ya da işletmenin geleceği için önemli görmemekte iken önemli olduğunu düşünenlerin ne kadarının pratikte bu teknolojilere yatırım yapacakları ya da bu bağlamda inisiyatif alacakları kocaman bir soru ișareti olarak durmaktadır.

Kald1 ki Toplum 5.0 gibi topyekûn toplumsal dönüşüm öngören bir inisiyatife toplumu hazırlamak mevcut şartlarda ütopya olarak addedilebilir. Bu dönüşümü gerçekleştirebilmenin yolu eğitimden geçmektedir. Ancak bu da 
müfredata birkaç ders eklemekle mümkün olacak bir şey olmayıp eğitim politikalarında radikal bir dönüşümü kaçınılmaz kılmaktadır.

Tam da bu noktada yapılması gereken eğitim reformunun; dijital okuryazarlık, çalışanların dijital beceriler üzerine eğitilmesi, sürdürülebilir büyümeye yönelik kapsamlı ekonomi politikaları, KOBI'lerin ve gelişmekte olan ülkelerin küresel değer zincirlerine daha iyi entegrasyonunu sağlayacak e-ticaret modelinin düzenlenmesi yapılması öngörülen bu dönüşümün etkili ve insan yararına olmasına yönelik Toplum 5.0 açılımlarından bazıları olarak görülmektedir. $\mathrm{Bu}$ bağlamda özellikle eğitim sistemlerinin bireysel yetenekleri ve yönelimleri merkeze koyarak uzmanlık alanlarında, kişisel gelişimi destekleyecek biçimde ve yaratıcılık üzerine şekillendirilmesi gerektiği uzmanlarca ifade edilmektedir (Şeneler, 2019). Konunun temelinde eğitim olsa da bu çemberin dişına çıkılması durumunda karşılaşılması olası görünen ve aşılması gereken başka engeller ya da unsurlar da mevcuttur. Japonya İş Federasyonu Keidanren, Toplum 5.0'in geliştirilebilmesi ve yaygınlaştırılabilmesi için karşılaşılması olası beş önemli unsuru;

- Hukuk sistemindeki engeller,

- Nesnelerin dijitalleşmesindeki bilimsel boşluklar,

- Kalifiye personel eksikliği,

- Sosyo-politik önyargılar,

- Toplumsal direnç

olarak belirtmiştir. Keidanren, bu bariyerlerin yıkılması ve Toplum 5.0'ın sağliklı biçimde hayata geçirilebilmesi için toplumların iş birliği içinde olması gerektiğine de vurgu yapmaktadır (Keidanren, 2018). Görüldüğü gibi sadece sanayide yapılacak teknolojik bir dönüşüm söz konusu değişimin sadece küçük bir parçası olup asıl odaklanılması gereken sosyal konulardır. Yasa yapıcılara ve yürütmeye de hukukî dönüşüm ve şeffaf yönetim anlamında bu süreçte büyük görev düşmektedir. Zira açı toplum fenomeni Toplum 5.0'1n olmazsa olmaz unsurlarından biridir.

\section{SONUÇ}

Japonya İş Federasyonu Keidanren, 2016 yılında Toplum 5.0'1, tüm endüstrilerde ve sosyal faaliyetlerde çeşitli yeni nesil teknolojileri bir araya getiren ve öncelikle Birleşmiş Milletler tarafindan oluşturulan sürdürülebilir kalkınma hedeflerine dayalı ekonomik kalkınmaya ve önemli sosyal sorunlara çözümlere ulaşan yeni bir toplumun sürdürülebilir vizyonu olarak başlatmıştır. Toplum 5.0, kurumlarda Kurumsal Sosyal Sorumluluk işleyiş̧ine ve davranışına yeni bir anlayış ve değişiklik önermek için modern toplumun önde gelen koşullarının tanınmasına dayanmaktadır. Endüstri 4.0'1 ve toplumun sürdürülebilir gelişimi için toplumdaki önem arz eden sosyal sorunların çözülmesini sağlayan yeni teknolojileri dikkate almaktadır. Japonya'nın Toplum 5.0 paradigmasını geliştirmesi ve tanıtması sadece 
teorik bir uygulama değil, Japonya'daki milyonlarca insanın yaşamını etkilemesi beklenen somut bir gerçek dünya projesidir.

Toplum 5.0 kendiliğinden gelen bir kavram değil, birlikte yaratılacak olan bir ortak girişimdir. Bu toplumun ana oyuncusu teknoloji değil insandır. Çok farklı hayal gücü, yaratıcılık ve değerlerle farklılık yaratan kişiler tarafindan gerçekleştirilecek olan bir topluluktur. Toplum 5.0, toplumun paydaşları arasında sosyal açıdan sorumlu gelişime olan ilgiyi yeniden değerlendirmiş, çevre teorisyenleri sosyal sorumluluğu öncelikle doğal ve sosyal refahın özlemi olarak tanımlamışlardır. Bu nedenle Toplum 5.0, insan merkezli toplumda faaliyet gösteren kuruluşlarda kurumsal sosyal sorumluluğun daha da geliştirilmesi için kuruluşların ekonomik çıkarlarını ve hedeflerini umut verici girişimler olarak kabul etmiştir. $\mathrm{Bu}$ pragmatik yaklaşım, piyasa ekonomisinin mevcut koşullarında kurumsal sosyal sorumluluğun artmasını sağlamakta ve daha fazla sürdürülebilir ekonomik sistemlerdeki kurumsal sosyal sorumluluğu desteklemektedir.

$\mathrm{Bu}$ felsefe her alanda tek merkezi reddeden; yani ademi merkeziyetçi, yerinden yönetimi ve farklılıkları destekleyen, dağıtık bir sistemi öngörmektedir. Bu anlamda yapılması öngörülen her türlü reform bu amaç doğrultusunda gerçekleştirilmek durumundadır. Özellikle pek çok anlamda hantal olduğu bilinen kamu sektörüne bu konuda büyük iş düşmektedir, sahip olduğu alışkanlıkları değiştirmesi ve ezber bozması kaçınılmaz biçimde gerekmektedir.

Konu Türkiye bağlamında ele alındığında ise başta karar vericiler olmak üzere bilim insanlarına, eğitimcilere, medyaya ve genel olarak topluma çok daha büyük iş düşmektedir. Zira Türkiye özelinde düşünüldüğünde alınması gereken yol batılı ya da Japonya, Güney Kore gibi gelişmişlik endeksinde üst sıralarda bulunan ülkelerle ile kıyaslandığında çok daha fazladır.

\section{KAYNAKÇA}

Azuma, R. (1997). A Survey of Augmented Reality. Presence: Teleoperators and Virtual Environments, 6(4), 355-385.

Bilim Sanayi ve Teknoloji Bakanlığı (2019). Türkiye'nin Sanayi Devrimi:

Dijital Türkiye Yol Haritası.
https://www.gmka.gov.tr/dokumanlar/yayinlar/2023_Dijital-Turkiye-YolHaritasi.pdf, (Erişim tarihi: 28.07.2020).

BIM Teknoloji (2019). Karışık Gerçeklik ve BIM. (BIM Teknoloji). https://www.bimteknoloji.com/teknoloji/karisik-gerceklik-ve-bim/, Erişim tarihi: (26.08.2020). 
Birleşmiş Milletler (2015). About the Sustainable Development Goals. (United Nations). https://www.un.org/sustainabledevelopment/sustainabledevelopment-goals/, Erişim tarihi: (02.06.2020).

Butler, T. (2020). What's Next in the Digital Transformation of Financial Industry? IT Professional, 22(1).

Büyükgöze, S., \& Dereli, E. (2019). Toplum 5.0 ve Dijital Sağlık. IV. Uluslararası Bilimsel ve Mesleki Çalışmalar Kongresi-Fen ve Sağlık, (7-10 Kasım 2019). Ankara, Türkiye.

Cabinet Office, Government of Japan. (2018). Examples of Creating New Value in the Field of Agriculture. Aralık 2, 2020 tarihinde Cabinet Office: https://www8.cao.go.jp/cstp/english/society5_0/agriculture_e.html, Erişim tarihi: (02.12.2020)

Cabinet Office, Government of Japan. (2018). Examples of Creating New Value in the Field of Disaster Prevention. https://www8.cao.go.jp/cstp/english/society5_0/bosai_e.html, Erişim tarihi: $(02.12 .2020)$

Cabinet Office, Government of Japan. (2018). Examples of Creating New Value in the Field of Food Products. https://www8.cao.go.jp/cstp/english/society5_0/food_e.html, Erişim tarihi: (02.12.2020)

Canlığlu, G. (2008). Değişen Toplum Yapılarında Bilginin Değişen Копити. (Yayımlanmamış Yüksek Lisans Tezi). Marmara Üniversitesi, Türkiyat Araştırmaları Enstitüsü, Bilgi ve Belge Yönetimi Anabilim Dalı, İstanbul.

Deguchi, A. (2020). Society 5.0 and its application to American smart cities. https://www.americancityandcounty.com/2020/06/10/society-5-0-and-itsapplication-to-american-smart-cities/, Erişim tarihi: (01.12.2020)

Develi, H. (2017). Endüstri 4.0'dan Toplum 5.0'a. (Dünya Gazetesi) https://www.dunya.com/kose-yazisi/endustri-40dan-toplum-50a/389146, Erişim tarihi: (02.06.2020).

Dijital Akademi (2019). Dijital Dönüşüm. (TÜBİTAK - BİLGEM - YTE). https://www.dijitalakademi.gov.tr/dijital-donusum-nedir, Erişim tarihi: (24.08.2020).

Erkılıç, C. E., \& Yalçın, A. (2020). Evaluation of the wearable technology market within the scope of digital health technologies. Gazi İktisat ve İşletme Dergisi, 6(3), 310-323. 
Esen, B. A. (2018). API Nedir? Entegrasyonu nasıl yapılır? (Medium) Ağustos 26, 2020 tarihinde https://medium.com/@akanesen/api-nedirentegrasyonu-nas\%C4\%B11-yap\%C4\%B11\%C4\%B1r-578f93578e46, Erişim tarihi: (26.08.2020).

Frankiewicz, B., \& Chamorro-Premuzic, T. (2020). Digital Transformation Is About Talent, Not Technology. Harvard Business Review. https://hbr.org/2020/05/digital-transformation-is-about-talent-not-technology, Erişim tarihi: (24.07.2020).

Freyer, H. (1954). Industri Çă̆ı. (B. Akarsu, \& H. Batuhan, Çev.) İstanbul: İstanbul Üniversitesi Edebiyat Fakültesi.

Gözüküçük, M. (2020). Dijital Dönüşüm ve Ekonomik Büyüme. (Yayımlanmamış Yüksek Lisans Tezi). İstanbul Ticaret Üniversitesi, Sosyal Bilimler Enstitüsü, İktisat Anabilim Dalı, İstanbul.

Gündüz, M. Z., \& Daş, R. (2018). Nesnelerin interneti: Gelişimi, bileşenleri ve uygulama alanları. Pamukkale Üniversitesi Mühendislik Bilimleri Dergisi, 24(2), 327-335.

Healio. (2017). Somnapatch Possible Tool to Detect Sleep Apnea. https://www.healio.com/news/primary-care/20170622/somnapatch-possible-toolto-detect-sleep-apnea\#, Erişim tarihi: (03.12.2020).

HoloNext. (2020). Karma Gerçeklik (Mixed Reality) Nedir? https://holonext.com/karma-gercelik-nedir/, Erişim tarihi: (26.08.2020).

İçten, T., \& Bal, G. (2017). Artırılmış Gerçeklik Üzerine Son Gelişmelerin ve Uygulamaların İncelenmesi. Gazi Üniversitesi Fen Bilimleri Dergisi Part C: Tasartm ve Teknoloji, 5(2), 111-136.

i-SCOOP. (2020). Digital transformation: online guide to digital business transformation. https://www.i-scoop.eu/digital-transformation/, Erişim tarihi: (24.07.2020)

İşNet AŞ. (2020). API (Uygulama Programlama Arayüzü) Nedir? https://www.isnet.net.tr/BlogIcerik/api-nedir-isnet-blog, Erişim tarihi: (26.08.2020).

İTÜNOVA Teknoloji Transfer Ofisi. (2017). ABD İğnesiz Ölçüm Yapılabilen Kan Şekeri Ölçüm Cihazını Onayladı. http://blog.itunovatto.com.tr/fdaignesiz-olcum-yapilabilen-kan-sekeri-olcum-cihazini-onayladi/, Erişim tarihi: (03.12.2020). 
Kaleci, D., Tepe, T., \& Tüzün, H. (2017). Üç Boyutlu Sanal Gerçeklik Ortamlarındaki Deneyimlere İlişkin Kullanıcı Görüşleri. Türkiye Sosyal Araştırmalar Dergisi, 21(3), 669-689.

Keidanren (2018). Society 5.0 - CoCreating the Future. Keidanren Policy \& Action. https://www.keidanren.or.jp/en/policy/2018/095_proposal.pdf, Erişim tarihi: (04.08.2020).

Kent, E. (2019). Endüstri 4.0'dan Toplum 5.0'a. https://www.endustri40.com/endustri-4-0dan-toplum-5-0a/, Erişim tarihi: (01.12.2020).

Nakanishi, H., \& Kitano, H. (2018). Society 5.0: Co-Creating the Future. Tokyo: Keidanren Kaikan. https://www.keidanren.or.jp/en/policy/2018/095_booklet.pdf, Erişim tarihi: (02.06.2020).

Öztuna, B. (2019). Toplum 5.0 (Süper Akıllı Toplum). Ankara: Ekin Basım Yayım Dağıtım.

CES.

Perry, T. (2016). Stretchable Electronics Have Their Coming Out Party At valley/biomedical/devices/stretchable-electronics-have-their-coming-out-party-atces, Erişim tarihi: (03.12.2020).

Sarı, R. (2019). Dijital Dönüşüm Çağında Büyük Veri ve Yapay Zeka. https://www.bezelyedergi.net/post/dijital$\mathrm{d} \% \mathrm{C} 3 \% \mathrm{~B} 6 \mathrm{n} \% \mathrm{C} 3 \% \mathrm{BC} \% \mathrm{C} 5 \% 9 \mathrm{~F} \% \mathrm{C} 3 \% \mathrm{BCm}-\% \mathrm{C} 3 \% \mathrm{~A} 7 \mathrm{a} \% \mathrm{C} 4 \% 9 \mathrm{~F} \% \mathrm{C} 4 \% \mathrm{~B} 1 \mathrm{nda}-$ b\%C3\%BCy\%C3\%BCk-veri-ve-yapay-zeka, Erişim tarihi: (25.08.2020).

Sezer, B. (2018). Batı Dünya Egemenliği ve Endüstri Devrimi. İstanbul: Doğu Kitabevi.

Sotelo, R. (2019). Quantum Computing: What, Why, Who. IEEE CHILEAN Conference on Electrical, Electronics Engineering, Information and Communication Technologies (CHILECON) (13-27 Kasim 2019). Valparaiso, Şili.

Şeneler, Ç. (2019). Toplum 5.0; insanların, robotların ve yapay zekanın güç birliğini temsil ediyor. Anadolu Ajansı Şirket Haberleri. (A. Durdak, Röportaj Yapan). https://www.aa.com.tr/tr/sirkethaberleri/egitim/toplum-50-insanlarinrobotlarin-ve-yapay-zekanin-guc-birligini-temsil-ediyor/652354, Erişim tarihi: (28.07.2020). 
Taş, H. (2018). Dördüncü Sanayi Devrimi’nin (Endüstri 4.0) Çalışma Hayatına ve İstihdama Muhtemel Etkileri. OPUS - Uluslararası Toplum Araştırmaları Dergisi, 9(16), 1817-1836.

Tucker, P. (2010). What Quantum Computing Means for National Security: Researchers Look to a Radically Advanced Computer Environment and a New Era of Cybersecurity Threats. The Futurist, 44(4), 6-7.

Turan, M. (2014). Bulut Bilişim ve Mali Etkileri: Bulutta Vergi. Bilgi Dünyast, 15(2), 296-326.

TÜBİTAK (2016). Yeni Sanayi Devrimi: Ak1llı Üretim Sistemleri Teknoloji Yol Haritası. Ankara: TÜBİTAK Bilim, Teknoloji ve Yenilik Politikaları Daire Başkanlı̆̆ı.

https://www.tubitak.gov.tr/sites/default/files/akilli_uretim_sistemleri_tyh_v27arali k2016.pdf, Erişim tarihi: (28.07.2020).

TÜBITTAK BİLGEM.

https://blokzincir.bilgem.tubitak.gov.tr/blok-zincir.html, (25.08.2020).

Uçkun vd. (2002). Bilgi Toplumu ve Türkiye. I. Ulusal Bilgi Ekonomi ve Yönetim Kongresi (10-11 Mayıs 2002). Kocaeli.

Wise, C. (2018, Mayis 23). This digital pill wants to make following your prescription easier. https://www.pbs.org/newshour/science/following-aprescription-is-hard-this-digital-pill-wants-to-help, Erişim tarihi: (03.12.2020). 